\title{
THE EFFECTS OF LOCAL HEATING OF THE TESTIS ON THE FLOW AND COMPOSITION OF RETE TESTIS FLUID IN THE RAT, WITH SOME OBSERVATIONS ON THE EFFECTS OF AGE AND UNILATERAL CASTRATION
}

\author{
B. P. SETCHELL AND G. M. H. WAITES \\ Department of Biochemistry, A.R.C. Institute of Animal Physiology, \\ Babraham, Cambridge, and \\ Department of Physiology and Biochemistry, University of Reading, \\ Reading, Berks
}

(Received 30th Fune 1971, accepted 7th Fanuary 1972)

\begin{abstract}
Summary. The concentration of spermatozoa in the rete testis fluid of rats increased gradually with age and reached adult levels at about $250 \mathrm{~g}$ body weight, whereas fluid secretion per unit weight of testis reached adult rates at a body weight of about $100 \mathrm{~g}$. Unilateral castration had no effect on the weight of the remaining testis or on its fluid secretion; sperm concentration in rete testis fluid was only affected in very young rats. Local heating of the testes of rats was followed by a fall in the sperm concentration in rete testis fluid beginning between 6 and 10 days, and lasting until 39 days, after heating. This fall was associated with a decrease in testis weight which persisted after the concentration of spermatozoa in rete testis fluid had returned to normal. However, there was no change in fluid secretion per unit weight of testis, nor was there any change in the concentration of inositol, glycine or potassium in rete testis fluid.
\end{abstract}

\section{INTRODUCTION}

The deleterious effects of increased temperature on the function of the testis are now well known (for references, see the recent reviews by Waites \& Setchell, 1969; VanDemark \& Free, 1971). Recently, it was shown that in rams the number of spermatozoa leaving the testis in rete testis fluid was normal for about 21 days after heating but thereafter fell dramatically, although the fluid itself continued to flow at normal rates (Setchell, Voglmayr \& Hinks, 1971).

Because of the difficulties inherent in the techniques used, these results were based on only six animals, and it seemed desirable to extend these observations using more animals and, at the same time, to obtain data on another species. Rete testis fluid can now be collected from rats (Tuck, Setchell, Waites \& Young, 1970), but before the experiments to study the effects of heat on the testis could begin, it was first necessary to establish when the concentration of 
spermatozoa in the rete testis fluid reached adult levels so that sexually mature rats could be used. Some observations have also been made on the effects of unilateral castration on fluid secretion and sperm production by the remaining testis.

\section{MATERIALS AND METHODS}

White rats of Wistar and Sprague Dawley (C.S.E.) strain were used. They were kept in a room at $20^{\circ} \mathrm{C}$ and fed commercial rat cubes ('Oxoid' Diet 41B). In the experiment on the effects of age, sixty-five rats between 20 and 90 days old,

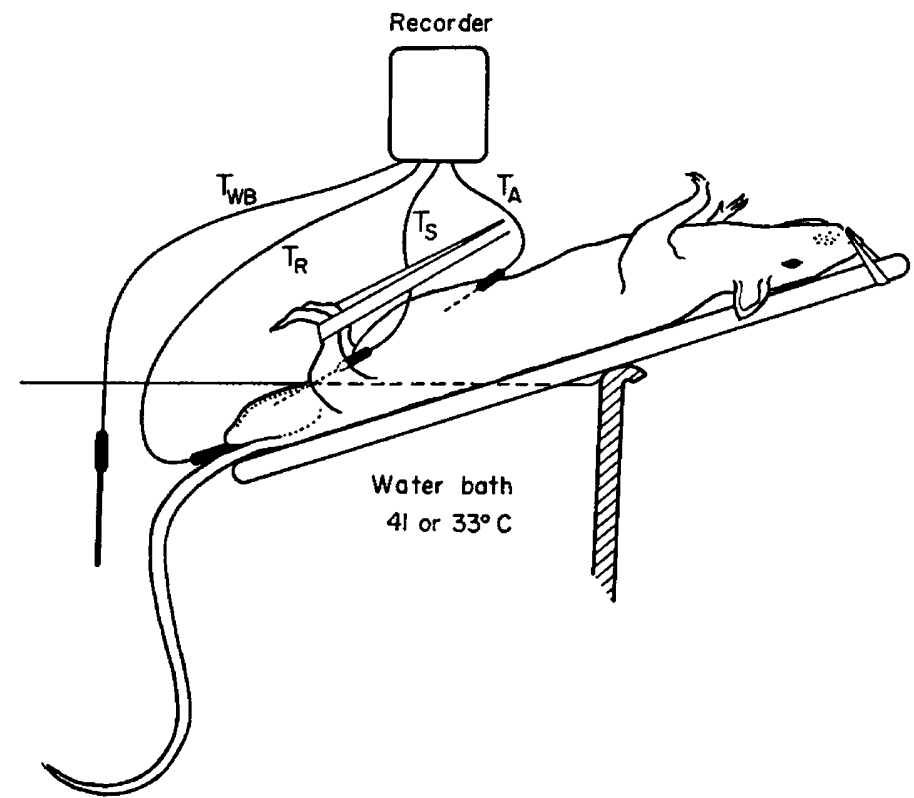

Texr-FIG. 1. A diagram of the orientation of the rat during immersion of its testes in a water bath at 41 or $33^{\circ} \mathrm{C}$. $T_{W_{B}}, T_{R}, T_{S}$ and $T_{A}$ : thermistor probes measuring the temperature in the water bath, rectum, subcutaneous scrotal tissue and abdomen respectively.

and weighing between $43 \mathrm{~g}$ and $260 \mathrm{~g}$, were used. The values from these rats were also used as controls for comparison with those from forty-eight other rats which were unilaterally castrated when they were 35,49 or 61 days old; the efferent ducts were ligated 1, 2, 4 or 8 weeks later and rete testis fluid was collected as described by Tuck et al. (1970).

In the heat experiment, 188 rats were used. They were about 90 days old and weighed 216 to $363 \mathrm{~g}$ at the time of heating. When fluid was collected from them 0 to 60 days later, they weighed 250 to $440 \mathrm{~g}$.

The testes were heated for 1 or $1 \frac{1}{2} \mathrm{hr}$, the rat being lightly anaesthetized with an intraperitoneal injection of pentobarbitone sodium $(5 \mathrm{mg} / 100 \mathrm{~g}$ body weight) and held on its back on a wooden platform. The platform was tilted (Text-fig. 1) so that, with the hind legs supported in air, the scrotum and tail were immersed in water at 41 or $33^{\circ} \mathrm{C}$. Subcutaneous scrotal and rectal temperatures 
were recorded by thermistors supported by hypodermic needles (Grant Instruments Ltd, Toft, Cambridge). The animal was then dried and allowed to recover consciousness. At intervals between 1 and 60 days after heat treatments, groups of four rats were lightly anaesthetized with ether and their efferent ducts were ligated on one side. The efferent ducts of one group of four rats were ligated immediately before exposure of the scrotal area to heat. Fluid was collected from the distended rete testis $24 \mathrm{hr}$ later under pentobarbitone anaesthesia. A number of control rats were correspondingly prepared. The fluid was collected into pre-weighed tubes containing $0.5 \mathrm{ml}$ of $0.9 \% \mathrm{NaCl}$ with $0.01 \%$ Triton-X-100 to prevent the spermatozoa clumping together and thus making counting impossible. When sufficient fluid $(0.02$ to $0.2 \mathrm{ml}$ ) had been collected, the catheter was withdrawn and both testes were removed, weighed and dried. The fluid accumulating in the testes was calculated as described by Setchell (1970) and the weight of fluid collected by catheter was added to give the total amount of fluid secreted during the previous $24 \mathrm{hr}$.

\section{Analytical techniques}

Sperm counts were made immediately using a haemocytometer. The rest of the saline-diluted fluid was then centrifuged at $3000 \mathrm{~g}$ for $10 \mathrm{~min}$ and the supernatant was stored at $-20^{\circ} \mathrm{C}$. Potassium was estimated in this fluid using a flame photometer (Evans Electroselenium Ltd, Harlow, Essex), inositol by yeast assay with Kloeckera brevis (Campling \& Nixon, 1954) and glycine by a modification of the technique of Umberger \& Fiorise (1963). Diluted fluid $(0.2 \mathrm{ml})$ was dried over silica-gel and the residue taken up in $20 \mu \mathrm{l}$ water. Dry pyridine $(0.5 \mathrm{ml})$ was added then $150 \mathrm{mg}$ solid p-nitrobenzoyl chloride. The precipitate was dissolved by the addition of chloroform $(3 \mathrm{ml})$ and the colour measured at $490 \mathrm{~nm}$.

\section{RESULTS}

\section{Effects of age}

As previously observed (Setchell, 1970), secretion of fluid by the testis was indicated by the increase in weight or water content after EDL, and began when the testis attained a weight of about $0.5 \mathrm{~g}$ at a body weight of about $90 \mathrm{~g}$. Thereafter, fluid secretion per unit weight of testis rapidly reached adult rates.

Fluid collected from the rete testis of rats weighing about $90 \mathrm{~g}$ was almost devoid of spermatozoa which only appeared in the fluid from rats weighing about $150 \mathrm{~g}$ or more. The control testis weight (Text-fig. 2) and the concentration of spermatozoa continued to increase with body weight up to about $250 \mathrm{~g}$ (Text-fig. 3). In previous studies, the ratio of water content was considered to be a more reliable index of fluid secretion because the two testes of one animal varied less in water content than in weight. However, the increment in weight was more useful in the present experiments because it gave an absolute measurement of the fluid retained in the seminiferous tubules and rete testis, and if multiplied by the concentration of spermatozoa in the fluid, yielded an estimate of sperm production. 


\section{Unilateral castration}

The effect of unilateral castration of rats at different ages on the weight of the remaining testis is shown in Text-fig. 2. Fluid secretion is usually estimated from the difference in weight or water content between the ligated efferent duct (EDL) and unligated testes of the same animal, expressed as a ratio of

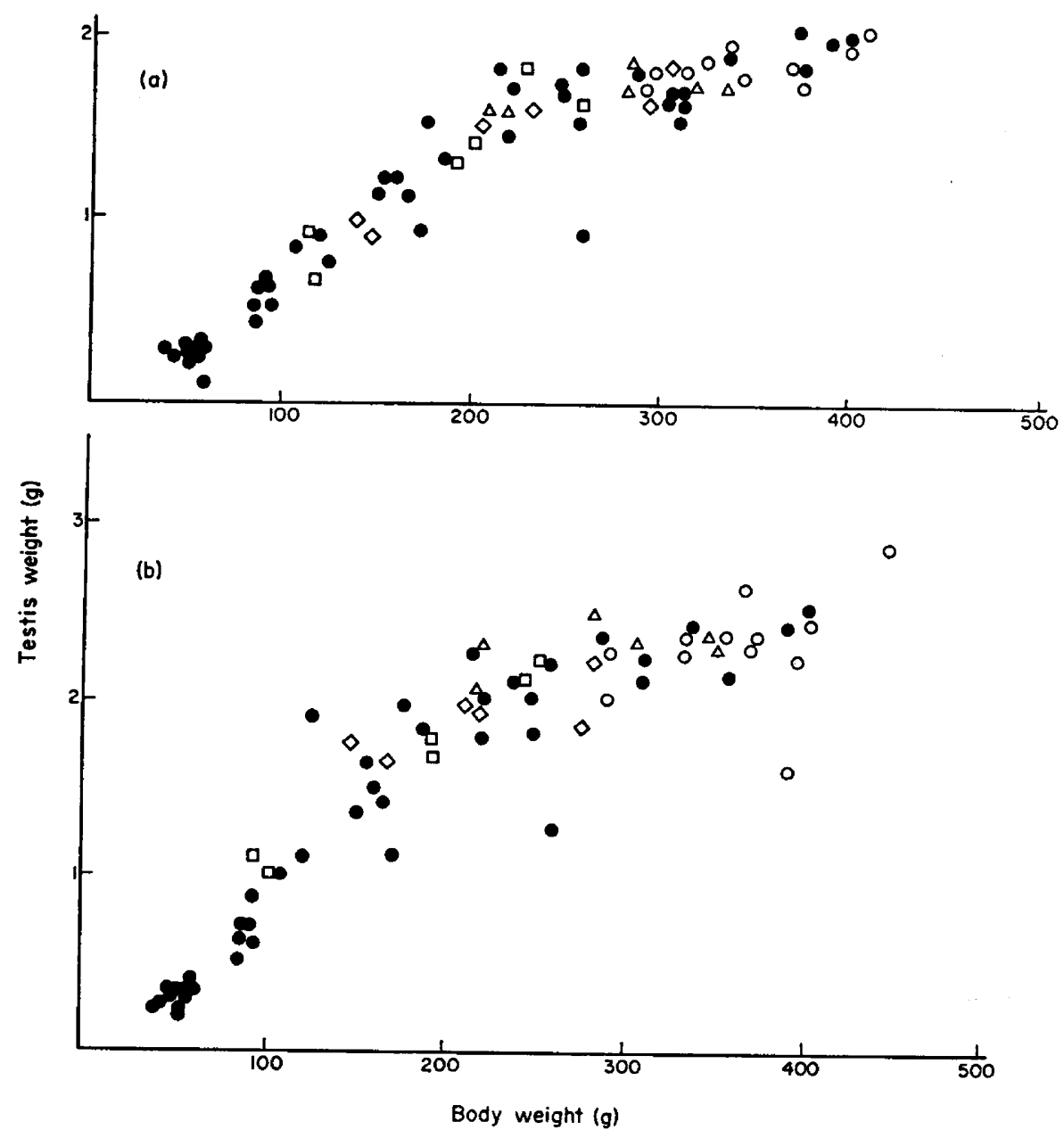

TExr-FIo. 2. The weights of the unligated (a) and 24-hr EDL (b) testes of intact rats (O) of various ages and of rats unilaterally castrated $1(\square), 2(\diamond), 4(\Delta)$ or $8(0)$ weeks previously at the ages of 35,49 or 61 days.

the EDL to the control unligated testis (Setchell, 1970). Obviously, this is impossible for a unilaterally castrated rat, but as neither the unligated nor the EDL testes differed consistently in weight or water content from the corresponding testes of intact rats of the same body weight, it can be concluded that unilateral castration has no effect on fluid secretion. The sperm concentration of the rete testis fluid was also unaffected by unilateral castration, except for a possible slight increase in the two youngest rats (Text-fig. 3 ). 
Effects of heating the testes

The subcutaneous temperature in the scrotum rose to $41^{\circ} \mathrm{C}$ in about $4 \mathrm{~min}$ after immersion in water at $41^{\circ} \mathrm{C}$ and remained within $0.2^{\circ} \mathrm{C}$ of this value throughout. Rectal temperature rose gradually from $35.3 \pm 0.2^{\circ} \mathrm{C}$ during the first $30 \mathrm{~min}$ of heating and then remained stable at $39.8 \pm 0.1^{\circ} \mathrm{C}$ after $60 \mathrm{~min}$ and $39 \cdot 2 \pm 0.4^{\circ} \mathrm{C}$ after $90 \mathrm{~min}$. Intra-abdominal temperature recorded simultaneously in eight heated rats was 1.2 to $1.4^{\circ} \mathrm{C}$ lower than rectal temperature. In the control rats, scrotal temperature remained in the range 32 to $33^{\circ} \mathrm{C}$ throughout immersion in water at $33^{\circ} \mathrm{C}$. Their rectal temperatures slowly fell from $36 \cdot 4 \pm 0 \cdot 2^{\circ} \mathrm{C}$ to $35 \cdot 0 \pm 0.4^{\circ} \mathrm{C}$ after $60 \mathrm{~min}$ and $34.5 \pm 0.8^{\circ} \mathrm{C}$ after $90 \mathrm{~min}$.

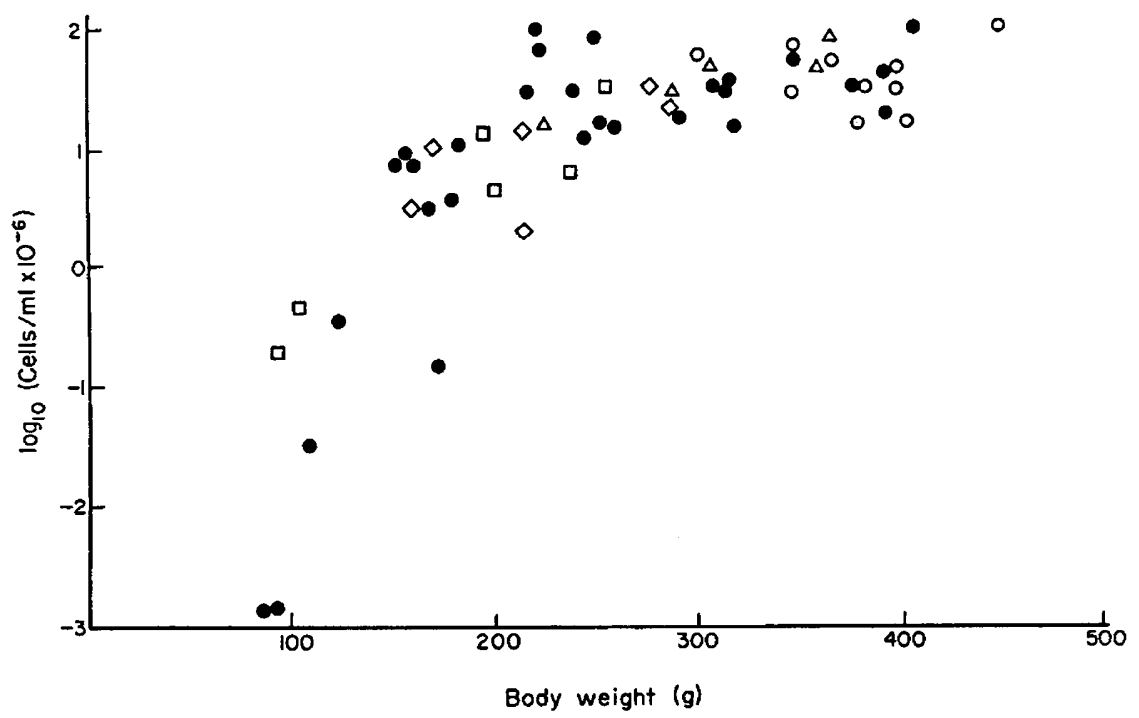

Texr-Fig. 3. The concentration of spermatozoa in the rete testis fluid from intact rats (๑) of various ages and from rats unilaterally castrated. $1(\square), 2(\Delta), 4(\Delta)$ or $8(0)$ weeks previously at the ages of 35,49 or 61 days.

The concentration of spermatozoa in rete testis fluid decreased in one rat 6 days after heating the testes, and in all rats after 10 days, to about one thousandth of normal. The sperm concentration remained low for 38 days and then abruptly increased to normal values (Text-fig. 4).

Fluid secretion, calculated from the ratio of the weight of the EDL testis to the contralateral control testis, continued at the normal rate per unit weight of testis after heating, but because the testis weight (both wet weight and dry weight) fell to almost half the control weight within 4 days (Text-fig. 5), the total volume of fluid secreted was reduced.

The concentrations of potassium, inositol and glycine in the rete testis fluid were not related to the concentration of spermatozoa. However, there was considerable variation in the values obtained, probably due to errors in measuring the volume of fluid collected from the catheter. This did not appear to affect the results on concentration of spermatozoa to the same extent because of the larger changes observed in sperm concentration. 


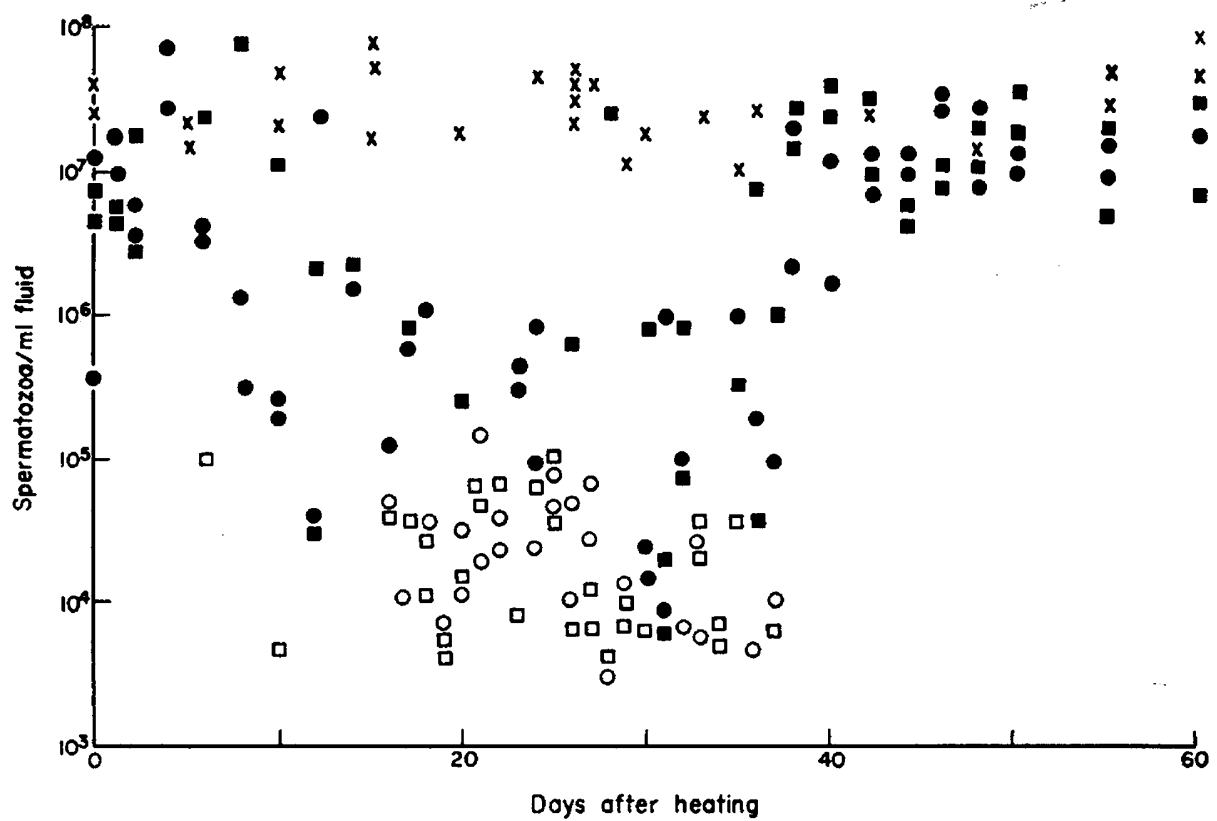

Texr-pig. 4. The concentration of spermatozoa in rete testis fluid of rats at various times after heating the scrotum and testes. $\times$ : testes immersed in water at $33^{\circ} \mathrm{C}$ for $1 \mathrm{hr}$; $O$, : testes immersed in water at $41^{\circ} \mathrm{C}$ for $1 \mathrm{hr} ; \square, \square$ : testes immersed in water at $41^{\circ} \mathrm{C}$ for $1 \frac{1}{2} \mathrm{hr}$. In the samples represented by hollow symbols, no spermatozoa were seen in the haemocytometer. For graphical representation, it has been assumed that one spermatozoon was present and the 'sperm counts' have been calculated accordingly. The actual concentration must have been below this value. The variation in these 'counts' is, thus, a reflection of the volume of the sample of rete testis fluid collected.

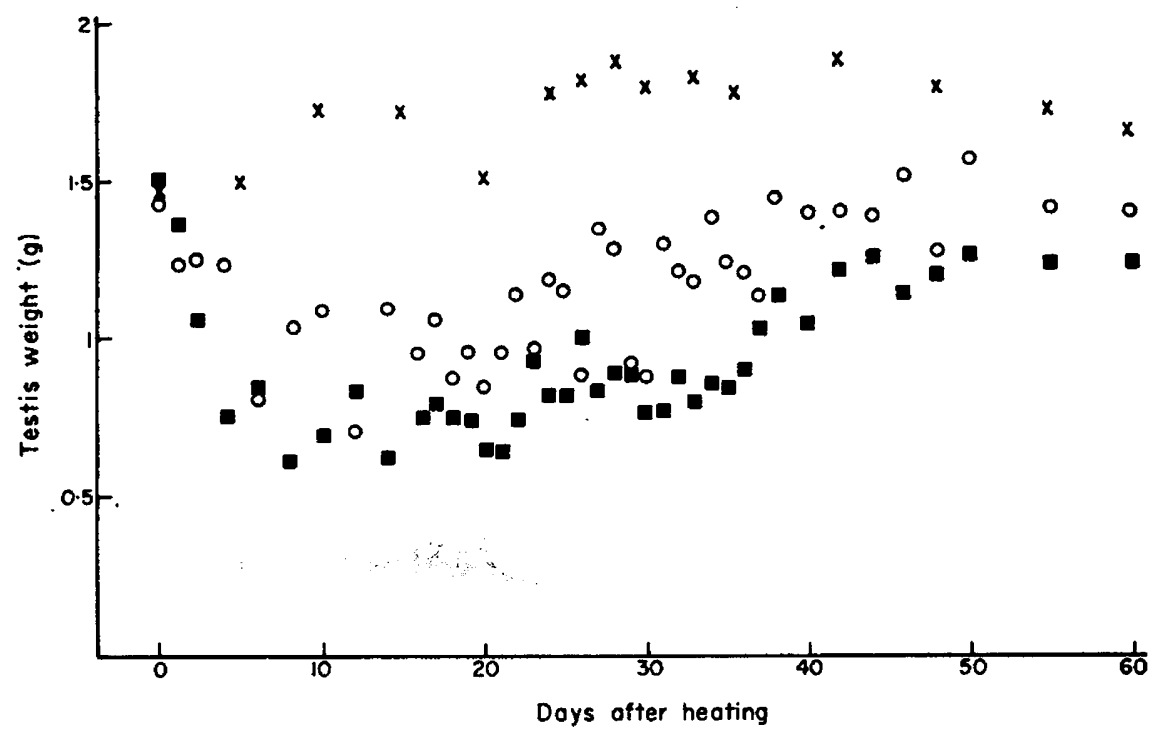

TEXT-FIG. 5. The weight of the unligated testes of rats at various times after heating the scrotum and testes. $x$ : testes immersed in water at $33^{\circ} \mathrm{C}$ for $1 \mathrm{hr} ; 0$ : testes immersed in water at $41^{\circ} \mathrm{C}$ for $1 \mathrm{hr}$; 1 : testes immersed in water at $41^{\circ} \mathrm{C}$ for $1 \frac{1}{2} \mathrm{hr}$. Each point is the mean of two animals; the individual values seldom differed from the mean by more than $10 \%$. 


\section{DISCUSSION}

Collection of spermatozoa and fluid by cannulation of the rete testis should give an accurate assessment of the time-course of damage to the germinal and secretory epithelium after heat. The number of spermatozoa leaving the testis in the ram was reduced by heating the testis to body temperature, or just above, for $3 \mathrm{hr}$ (Setchell et al., 1971). A similar effect, but with a different time-course, was observed here after heating the testes of rats to $41^{\circ} \mathrm{C}$ for 1 or $1 \frac{1}{2} \mathrm{hr}$. This temperature is about $4^{\circ} \mathrm{C}$ higher than deep body temperature for rats but was chosen as the lowest temperature compatible with satisfactory anaesthesia and recovery, although it is still somewhat above threshold for damage to the rat germinal epithelium. Nevertheless, it is close to the temperature to which the rams were exposed (Setchell et al., 1971) and it is at least possible that rat testes could be exposed to such temperatures under natural conditions. By these criteria, the higher temperatures applied to rats by Chowdhury \& Steinberger (1964, 1970) and Collins \& Lacy (1969) must be considered unphysiological. It is essential to apply temperatures to the testis which would not damage other organs of the body if one is to argue that the effects observed are specific to the testis and there is some suggestion that a temperature of about $41^{\circ} \mathrm{C}$ marks a natural upper limit. It is about the temperature at which mammalian cutaneous 'warm' receptors, including those in rat scrotal skin, respond maximally (Iggo, 1969). Hypothalamic temperatures greater than $41^{\circ} \mathrm{C}$ provoke extreme thermoregulatory responses completely different in character from those produced at lower temperatures (Bligh, 1966).

There is an abrupt change at $41^{\circ} \mathrm{C}$ in the physical characteristics of mixtures of water and 1;2-dipalmitoyl-L-phosphatidylcholine (Chapman, 1972) and lipids similar to this compound are major constituents of the phospholipids of most mammalian cells including those of the testis (Oshima \& Carpenter, 1968). Other work on testicular blood flow (Waites, Setchell \& Fowler, 1968; Waites, Setchell \& Quinlan, 1972) and vascular permeability (Main \& Waites, unpublished observations) has shown that these parameters are unaltered by temperatures up to $41^{\circ} \mathrm{C}$ but that dramatic changes occur at higher temperatures.

The sperm concentration in the rete testis fluid of rats falls much sooner after heating than in rams in which normal numbers of spermatozoa appear for about 20 days (Setchell et al., 1971). In the rat, normal concentrations of spermatozoa were found in rete testis fluid for between 6 and 10 days after heating the testis; thereafter, the concentration began to fall. This indicates that heat must destroy some late spermatids and developing spermatozoa. The cells leaving the testis 6 days later would, at the time of heating, have been Type 16 spermatids at Stage II of the seminiferous cycle; those leaving 10 days after heating would have been Type 12 or 13 spermatids at Stage XII or XIII (see Clermont, Leblond \& Messier, 1959). Thereafter, the results would reflect damage to early stage spermatids, to cells in meiosis and to pre-meiotic spermatocytes back to the leptotene stage. The susceptibility of these cell types has already been suggested in the histological studies of Chowdhury \& Steinberger $(1964,1970)$. These authors also showed that pachytene spermatocytes in 
Stages V and VI were heat-resistant and produced nearly normal numbers of Step 18 and Step 19 spermatids 26 days later. Such cells would presumably appear in the testicular outflow a day or two later and should have brought a return to near normal sperm outflow in our experiment. In the present work, the testes of the rats subjected to local heating for $1 \mathrm{hr}$ increased in weight 26 days after heating, and one rat produced normal numbers of spermatozoa in its rete testis fluid 28 days after heating (Text-fig. 4).

The rapid reappearance of spermatozoa in the fluid flowing out of the rat testis 37 to 39 days after heating confirms the observations of Chowdhury \& Steinberger (1964) that resting primary spermatocytes, and cells deriving from the divisions of B-type spermatogonia immediately after the heating, develop normally. This would seem to confirm that a major species difference exists in the susceptibility of B-type spermatogonia to heat. In rams, these spermatogonia accumulate in prophase and metaphase during the first 2 days after heat because they begin to divide and eventually degenerate (Waites \& Ortavant, 1968). This spermatogonial loss presumably accounts for the secondary fall in sperm concentration in rete testis fluid collected from rams about 30 days after heat (Setchell et al., 1971). However, the testis from rats remained below normal weight for up to 60 days after heating, which implies that some cell types are still depleted at this stage. Histological studies are in progress to try to define which cells are involved.

Because of the difficulty in knowing how best to express the results on fluid secretion, our results can be interpreted as showing that after heating there is either no change in secretion per unit testis weight or a decrease in total secretion. As the secretory tissue is likely to be distinct from the germinal cells, the latter is probably more meaningful and, in this regard also, the rat appears to differ from the ram.

The continued secretion of fluid of normal characteristic composition during the period of low sperm concentration after heating and the known secretion of almost sperm-free fluid in young animals emphasize that fluid secretion is independent of complete spermatogenesis, although it is obviously an essential part of sperm production.

The absence of any clear-cut effects of unilateral castration conflicts with the results of Grant (1957), who recorded a $50 \%$ increase in volume of the remaining testis in mature rats 21 days after unilateral castration. More recently, Shellabarger (1963) found that the remaining testis did not hypertrophy after unilateral castration and Liang \& Liang (1970) found a significant but minuscule increase in weight. We cannot explain the difference between Grant's results and the others, but it would seem that the majority opinion is that the adult rat appears to be similar to the rabbit (Lipschutz, 1922) but different from the ram in which hypertrophy of the remaining testis does occur after unilateral castration (Voglmayr \& Mattner, 1968; Hochereau-de Reviers, 1971; and our own unpublished observations).

\section{AGKNOWLEDGMENTS}

We are most grateful to Mrs M. D. Collyer, Mr D. Constantiniou and $\mathrm{Mr}$ 
Richard J. Parrott for their assistance in the course of this experiment and to Mr R. W. White for inositol assays.

This research was supported by a Grant from the Population Council, New York.

\section{REFERENCES}

BuIGH, J. (1966) The thermosensitivity of the hypothalamus and thermoregulation in mammals. Biol. Rev. 44, 317.

Gampling, J. D. \& Nixon, D. A. (1954) The inositol content of foetal blood and foetal fluids. F. Physiol., Lond. 126, 71.

Chapman, D. (1972) Physical chemistry of phospholipids. In: Phospholipids, Form and Function. Eds. G. B. Ansell, R. M. G. Dawson and J. N. Hawthorne. Elsevier, Amsterdam.

Chowdhury, A. K. \& Steinberger, E. (1964) A quantitative study of the effect of heat on germinal epithelium of the rat testis. Am. F. Anat. 115, 569.

Ghowdhury, A. K. \& Steinberger, E. (1970) Early changes in the germinal epithelium of rat testes following exposure to heat. F. Reprod. Fert. 22, 205.

Glermont, Y., Leblond, C. P. \& Messier, B. (1959) Durée du cycle de l'épithélium du rat. Archs Anat. microsc. Morph. exp. 48, 37.

Gollins, P. \& LACY, D. (1969) Studies on the structure and function of the mammalian testis. II. Cytological and histochemical observations on the testis of the rat after a single exposure to heat applied for different lengths of time. Proc. $R$. Soc. B, 172, 17.

Grant, J. H. (1957) The effects of unilateral orchidectomy on the rat testis. Proc. Soc. Study Fert. 8, 27.

HochereaU-de Reviers, M. T. (1971) Unilateral castration in the ram. F. Reprod. Fert. 27, 498.

IGGo, A. (1969) Cutaneous thermoreceptors in primates and sub-primates. $\mathcal{F}$. Physiol., Lond. 200, 402.

Liang, D. S. \& Liang, M. D. (1970) Testicular hypertrophy in rats. F. Reprod. Fert. $21,537$.

Lipschutz, A. (1922) The so-called compensatory hypertrophy of the testicle after unilateral castration. 7. Physiol., Lond. 56, 451.

Oshima, M. \& Carpenter, M. P. (1968) The lipid composition of the prepubertal and adult rat testis. Biochim. biophys. Acta, 152, 479.

SeTchel, B. P. (1970) The secretion of fluid by the testes of rats, rams and goats with some observations on the effect of age, cryptorchidism and hypophysectomy. F. Reprod. Fert. 23, 79.

Setchell, B. P., Voglmayr, J. K. \& Hinks, N. T. (1971) The effect of local heating on the flow and composition of rete testis fluid in the conscious ram. F. Reprod. Fert. 24, 81.

Shellabarger, C. J. (1963) Compensatory hypertrophy of the thyroid gland, adrenal gland and the gonad studied singly or in combination. Endocrinology, 73, 124.

Tuck, R. R., Setchell, B. P., Wartes, G. M. H. \& Young, J. A. (1970) The composition of fluid collected by micropuncture and catheterization from the seminiferous tubules and rete testis of rats. Pfiugers Arch. ges. Physiol. 318, 225.

UMBerger, G. J. \& Fiorise, F. F. (1963) Detection and quantitative determination of glycine with pyridine and p-nitrobenzoyl chloride. Clin. Chem. 9, 79.

VanDemark, N. L. \& Free, M. J. (197I) Temperature effects. In: The Testis, Vol. III, p. 342. Eds. A. D. Johnson, W. R. Gomes and N. L. VanDemark. Academic Press, New York.

Voglmayr, J. K. \& Mattier, P. E. (1968) Compensatory hypertrophy in the remaining testis following unilateral orchidectomy in the adult ram. $\mathcal{F}$. Reprod. Fert. 17, 179.

Waites, G. M. H. \& Ortavant, R. (1968) Effets précoces d'une brève élévation de la température testiculaire sur la spermatogenèse du bélier. Annls Biol. anim. Biochim. Biophys. 8, 323.

Wartes, G. M. H. \& SETchell, B. P. (1969) Some physiological aspects of the function of the testis. In: The Gonads, p. 649. Ed. K. W. McKerns. Appleton, New York.

Waites, G. M. H., Setchelz, B. P. \& Fowler, D. G. (1968) Blood flow in the testis, epididymis and scrotum of rats during temperature elevation. Aust. 7. exp. Biol. med. Sci. 46, P 25.

Waites, G. M. H., Setchell, B. P. \& Quinlan, D. (1972) The effect of local heating of the scrotum, testes and epididymides of rats on cardiac output and regional blood flow. F. Reprod. Fert. (In press). 